\title{
Studies on the preparation of stem amaranth pickle
}

\author{
F. H. Shanta ${ }^{1}$, R. R. Rajib ${ }^{2^{\star}}$, M. A. Alim ${ }^{3}$ and M. R. Haque ${ }^{4}$ \\ 1,3 Department of Food Technology and Rural Industries Bangladesh Agricultural University Mymensingh-2022, ${ }^{2}$ Horticulture \\ Division, Bangladesh Institute of Nuclear Agriculture, Mymensingh-2202 and ${ }^{4}$ Agricultural Economics Division, \\ Bangladesh Institute of Nuclear Agriculture, Mymensingh-2202, Bangladesh, ${ }^{*} E-$ mail: rrrajib60@gmail.com
}

\begin{abstract}
Fresh stem amaranth was analyzed for proximate composition and the developed pickles were analyzed for proximate composition, microbiological status, sensory attributes and overall storage stability of the pickles. Pickle was prepareded with sugar, salt, oil and vinegar. Five formulations of stem amaranth were prepared. Fresh stem amaranth contains $96.0 \%$ moisture, $1.0 \%$ ash, $0.01 \%$ fat, $2.0 \%$ protein and $30 \mathrm{mg} / 100 \mathrm{~g}$ vitamin-C. The chemical analysis of pickles showed that moisture content was highly reduced in all processed samples. The microbiological studies revealed that total viable counts of bacteria and fungal growth were high in the pickles prepared without vinegar and sugar but it was low with vinegar-sugar-oil mix. The panelists marked for colour, flavor, texture and overall acceptability and analyzed statistically. Among five samples, the pickles prepared with vinegar-sugar-oil mix were the best. Storage studies were carried out up to six months at room temperature. Minor change was observed for color and flavor.
\end{abstract}

Keywords: Stem amaranth, Pickle, Microbiological status, Sensory attributes

\section{Introduction}

Stem amaranth (Amaranthus lividus) is the most common leafy vegetable belongs to the family Amaranthaceae grown during summer and rainy reason in Bangladesh. It fits well in a crop rotation because of its very short duration and long yield of edible matter per unit area. Both in area and production, it ranks $5^{\text {th }}$ in summer vegetable and $13^{\text {th }}$ among all vegetable (BBS, 2010). It contributes $5.42 \%$ in summer vegetables production. In Bangladesh, it is cultivated in an area of 25463 acre producing 65.98 thousand metric ton of fleshy edible part with per acre yield of 2.5 tones (BBS, 2010).

Pickling is one of the suitable and valuable method for processing and preservation of stem amaranth. When any food (fruits, vegetables, fish or meat) is preserved by natural salt solution or vinegar or oil or spices, then the processed food is called pickles. Pickles are widely acceptable and usable food item in Bangladesh as well as all over the world. The popular common pickles manufactured in Bangladesh by various industries available in the market are: mango pickles, mixed fruit pickle, olive pickle, chalta pickle and so on. But the qualities of these pickles are of question. The production and spoilage of the stem amaranth is higher in Bangladesh, hence an attempt was tried to minimize the spoilage and minimize the use of the low price abundantly and available stem amaranth (BBS, 2010). The present study was undertaken to develop pickles from stem amaranth, to analyze proximate composition of raw stem amaranth and pickle of stem amaranth, to observe the shelf life of processed products, to evaluate the microbiological status of pickles and to assess the overall acceptability of the processed pickles.

\section{Materials and Methods}

This study was conducted in the laboratories of the Department of Food Technology and Rural Industries under the faculty of Agricultural Engineering and Technology, Bangladesh Agricultural University, Mymensingh. Stem amaranth was collected from the local market

\section{Preparation of stem amaranth pickle}

The recipe of the pickles is given in Table 1. At first, the stem amaranth was washed, removed the peel, cut into pieces, blanched in boiling water for 3 to 4 minutes and dried in sun for 2 hours. Red chilli, turmeric, mustard and cumin powder and clove, cinnamon, cardamom, black pepper and aniseed pound and garlic, ginger, green chilli paste were used. Salt and sugar were also used. Then mustard oil was heated and put all the spices into the oil and heated continuaslly until the brown color formed. Then added the dried stem amaranth and fried for 5 minutes. After that the fried stem amaranth was cooled. Then fried stem amaranth pieces were mixed with vinegar. Then filled into sterilized jars and sealed airtight. Finally some extra oil was added (after heating and cooling oil) and then stored. This is the general process of preparation of stem amaranth pickle. The experiment was conducted with 5 (five) samples which are as follows: 
Sample $1\left(\mathrm{~S}_{1}\right)=$ Stem amaranth with oil +sugar + vinegar + blanching

Sample $2\left(\mathrm{~S}_{2}\right)=$ Stem amaranth with oil + sugar + vinegar and without blanching

Sample $3\left(S_{3}\right)=$ Stem amaranth with vinegar + sugar + blanching and without oil

Sample $4\left(\mathrm{~S}_{4}\right)=$ Stem amaranth with vinegar + oil + blanching and without sugar

Sample $5\left(\mathrm{~S}_{5}\right)=$ Stem amaranth with oil + blanching and without sugar and vinegar.

\section{Flow chart for stem amaranth pickles $\left(S_{1}\right.$ and $\left.S_{2}\right)$}

Stem amaranth $\rightarrow$ Washing $\rightarrow$ Peeling and cutting into pieces (1-1.5 inchs) $\rightarrow$ Blanching for 3-4 minutes (in boiling water) $\rightarrow$ Keeping in sun for two hours $\rightarrow$ Frying all spices in a little oil $\rightarrow$ Mixing stem amaranth pieces with fried spices $\rightarrow$ Frying the mixture for 5 minutes $\rightarrow$ Cooling $\rightarrow$ Addition of vinegar $\rightarrow$ Filling in $\mathrm{jar} \rightarrow$ Addition of oil after heating and cooling it $\rightarrow$ Storage

\section{Flow chart for stem amaranth pickles $\left(\mathrm{S}_{3}\right)$}

Stem amaranth $\rightarrow$ Washing $\rightarrow$ Peeling and cutting into pieces (1-1.5 inchs) $\rightarrow$ Blanching for 3-4 minutes (in boiling water) $\rightarrow$ Keeping in sun for two hours $\rightarrow$ Heating sugar and concentrate with vinegar $\rightarrow$ Mixing with ingredients $\rightarrow$ Cooling and filling into jar $\rightarrow$ Storage

\section{Flow chart for stem amaranth pickles $\left(S_{4}\right)$}

Stem amaranth $\rightarrow$ Washing $\rightarrow$ Peeling and cutting into pieces (1-1.5 inchs) $\rightarrow$ Blanching for 3-4 minutes (in boiling water) $\rightarrow$ Keeping in sun for two hours $\rightarrow$ Frying all spices in a little oil without sugar $\rightarrow$ Mixing stem amaranth pieces with fried spices $\rightarrow$ Frying the mixture for 5 minutes $\rightarrow$ Cooling $\rightarrow$ Addition of vinegar $\rightarrow$ Filling in jar $\rightarrow$ Addition of oil after heating and cooling it $\rightarrow$ Storage

\section{Flow chart for stem amaranth pickles $\left(\mathrm{S}_{5}\right)$}

Stem amaranth $\rightarrow$ Washing Peeling and cutting into pieces (1-1.5 inchs) $\rightarrow$ Blanching for 3-4 minutes (in boiling water) $\rightarrow$ Keeping in sun for two hours $\rightarrow$ Heating oil and mixing with other spices without sugar and vinegar $\rightarrow$ Mixing stem amaranth pieces with fried spices $\rightarrow$ Frying the mixture for 5 minutes $\rightarrow$ Cooling $\rightarrow$ Filling in jar $\rightarrow$ Storage

Table 1. Recipe of stem amaranth pickles :

\begin{tabular}{|c|c|c|c|c|c|}
\hline \multirow[t]{2}{*}{ Ingredients } & \multicolumn{5}{|c|}{ Sample } \\
\hline & $S_{1}$ & $\mathrm{~S}_{2}$ & $\mathrm{~S}_{3}$ & $\mathrm{~S}_{4}$ & $\mathrm{~S}_{5}$ \\
\hline Stem amaranth (g) & 500 & 500 & 500 & 500 & 500 \\
\hline Salt $(g)$ & 15 & 15 & 15 & 15 & 15 \\
\hline Onion (g) & 50 & 50 & 50 & 50 & 50 \\
\hline Ginger (g) & 25 & 25 & 25 & 25 & 5 \\
\hline Garlic (g) & 10 & 10 & 10 & 10 & 5 \\
\hline Red chilli powder $(\mathrm{g})$ & 15 & 15 & 15 & 15 & 10 \\
\hline Turmeric powder (g) & 15 & 15 & 15 & 15 & 15 \\
\hline Cumin powder $(\mathrm{g})$ & 5 & 5 & 5 & 5 & 5 \\
\hline Mustard (ground) (g) & 50 & 50 & 50 & 50 & 50 \\
\hline Cinnamon $(\mathrm{g})$ & 2 & 2 & 2 & 2 & 2 \\
\hline Cardamom (g) & 2 & 2 & 2 & 2 & 2 \\
\hline Black pepper (g) & 2 & 2 & 2 & 2 & 2 \\
\hline Aniseed (g) & 5 & 5 & 5 & 5 & 5 \\
\hline Clove (Nos) & 6 & 6 & 6 & 6 & 6 \\
\hline Vinegar (ml) & 150 & 150 & 600 & 150 & - \\
\hline Mustard oil (ml) & 400 & 400 & - & 250 & 400 \\
\hline Sugar (g) & 200 & 200 & 200 & - & - \\
\hline
\end{tabular}

\section{Proximate chemical analysis}

Proximate chemical composition represents the gross content of important chemical constituentsmoisture, ash, titrable acidity, $\mathrm{pH}$, fat, protein, total soluble solids and peroxide value. All was determined adopting AOAC(2004) method. These gave some positive indication as to the nutritive quality of the stem amaranth under investigation but this parameter can not be used to generalize the nutritive value of stem amaranth. 


\section{Microbiological examination}

\section{Determination of total viable bacteria}

For total viable count of bacteria present in stem amaranth pickles, standard plate count method was followed according to the method described in "Recommended method for the microbiological examination of food" (APHA, 2004). The microorganism growth in developed stem amaranth pickles was examined by visual observation at different storage periods.

\section{Sensory evaluation}

The consumer's acceptability of developed pickles was evaluated by a taste-testing panel. The hedonic rating test was used to determine the acceptability of the pickle. The panelists were selected from the teachers and students of Department of Food Technology and Rural Industries, Bangladesh Agricultural University, Mymensingh. Panelists were given score for characteristics color, flavor, texture and overall acceptability of processed stem amaranth pickles.

The scale was arranged such that

$9=$ Like extremely, $8=$ Like very much, $7=$ Like moderately, $6=$ Like slightly, $5=$ Neither like nor dislike, 4 = Dislike slightly, 3 = Dislike moderately, 2 = Dislike very much, 1 = Dislike extremely

\section{Storage studies}

The pickles were stored at room temperature. The deterioration of the products were observed at a regular interval of one month up to two months and at an interval of two months for the next four months. The color, flavor, texture and visual fungal growth etc. were observed up to the whole storage period.

\section{Results and Discussion}

The experiment was conducted to determine the effective means of processing and preservation of stem amaranth in the time when it is available.

\section{Proximate composition of fresh stem amaranth and stem amaranth pickles}

The composition of fresh stem amaranth is given in Table 2. Fresh stem amaranth contained $96.00 \%$ moisture, $1.00 \%$ ash, $0.01 \%$ fat, $2.00 \%$ protein and $30.0 \mathrm{mg} / 100 \mathrm{gm}$ vitamin-C. The percentage of moisture, protein, fat, ash and vitamin $\mathrm{C}$ were observed in the present study were very close to those reported by Srivastava and Kumar (2003). The analysis of developed pickles showed average moisture $69.2 \%$, ash $2.63 \%$, fat $0.13 \%$, protein $2.51 \%$, acidity $0.87 \%$, total soluble solid $31.20 \%$ and $\mathrm{pH} 4.02$. The stem amaranth pickles were analyzed for proximate composition immediately after processing (Table 3 ). The chemical compositions of stem amaranth pickles slightly varied depending on the processing ingredients used in the formulation, maturity stage of pickles, processing temperature etc. However, the composition remains very closer.

\section{Table 2. Chemical composition of raw stem amaranth}

\begin{tabular}{|l|c|c|c|c|c|}
\hline Name of Sample & Moisture content & Protein & Fat & Ash & Vitamin C (mg/ 1008) \\
\hline Raw stem amaranth & 96.00 & 2.00 & 0.01 & 1.00 & 30.00 \\
\hline
\end{tabular}

The initial moisture content of raw stem amaranth was $96.0 \%$ (Table 2) which was reduced after preparing different samples. The highest moisture content of pickle was $79 \%\left(\mathrm{~S}_{4}\right)$ and lowest was $63 \%$ $\left(S_{2}\right)$ (Table 3 ). The moisture content of $S_{1}$ and $S_{2}$ was $64 \%$ and $63 \%$ respectively. $S_{2}$ contained less moisture compared to $S_{1}$. This may be due to the effective of blanching because blanching caused the rupturing of stem amaranth and facilitate the absorption of water.

The initial protein content of raw stem amaranth was $2 \%$ which was slightly increased after the pressing of sample. The highest protein content of pickle was $2.80 \%\left(S_{1}\right)$ and the lowest was $2.15 \%\left(S_{4}\right)$. The initial fat content of raw stem amaranth was $0.01 \%$ which was very less and near to nil. But the content was slightly increased after the processing of sample. . It may be due to the use of oil and other spices. The highest fat content of processed sample was $0.17 \%\left(\mathrm{~S}_{5}\right)$ and the lowest was $0.08 \%\left(\mathrm{~S}_{3}\right)$. The fat content was less in $S_{3}$ because there was no use of oil in that sample. The initial ash content of raw stem 
amaranth was $1.0 \%$ which was significantly increased after the processing of sample. The highest ash content of processed sample was $3.0 \%\left(\mathrm{~S}_{1}\right)$ and the lowest was $2.11 \%\left(\mathrm{~S}_{3}\right)$. The cause of increasing ash content may be the use of various types of spices in the sample. The highest acidity of prepared sample was $0.95 \%\left(\mathrm{~S}_{4}\right)$ and the lowest was $0.70 \%\left(\mathrm{~S}_{5}\right)$. $\mathrm{S}_{4}$ contained more acidity than that $\mathrm{S}_{5}$. It may be due to the use of vinegar, in $S_{4}$ and no use of vinegar in $S_{5}$. The highest total soluble solids in stem amaranth pickle was $35 \%\left(S_{1}\right)$ and the lowest was $27 \%\left(S_{5}\right)$. $S_{1}$ contained more total soluble solids. It may be due to the use of sugar, vinegar, oil and other spices. The highest $\mathrm{pH}$ of processed sample was $3.80\left(\mathrm{~S}_{1}\right)$ and the lowest was $4.60\left(S_{5}\right)$ (Table 3$)$. Because of no use of vinegar, $S_{5}$ had the less $p H$ compared to $S_{1}$. The peroxide value of the processed samples was nil.

Table 3. Chemical composition of stem amaranth pickles

\begin{tabular}{|c|c|c|c|c|c|c|c|c|}
\hline Sample & Moisture (\%) & Protein (\%) & $\begin{array}{l}\text { Fat } \\
(\%)\end{array}$ & Ash (\%) & Acidity (\%) & $\begin{array}{c}\text { Total } \\
\text { Soluble } \\
\text { Solids (\%) }\end{array}$ & $\mathrm{pH}$ & $\begin{array}{c}\text { Per } \\
\text { Oxide } \\
\text { Value }(\%)\end{array}$ \\
\hline $\mathrm{S}_{1}$ & 64 & 2.80 & 0.12 & 3.00 & 0.90 & 35 & 3.80 & $\mathrm{Nil}$ \\
\hline $\mathrm{S}_{2}$ & 63 & 2.78 & 0.12 & 3.00 & 0.90 & 32 & 3.91 & Nil \\
\hline $\mathrm{S}_{3}$ & 65 & 2.62 & 0.08 & 2.11 & 0.92 & 34 & 3.95 & $\mathrm{Nil}$ \\
\hline $\mathrm{S}_{4}$ & 79 & 2.15 & 0.16 & 2.52 & 0.95 & 28 & 3.85 & $\mathrm{Nil}$ \\
\hline $\mathrm{S}_{5}$ & 75 & 2.20 & 0.17 & 2.56 & 0.70 & 27 & 4.60 & Nil \\
\hline
\end{tabular}

The covering oil and sugar as well as salt prevent microbial contamination. When pickle fried with oil, it's moisture content decreased as a result microbial contamination reduced because microorganism favor moisture. So Lower moisture content means higher amounts of nutrients. Ranni (1992) found that the safe moisture content in mango pickles to be as high as $65.0 \%$ which is closed to the result obtained for stem amaranth pickles. From (Table 3) the result we found the highest moisture content $(79.0 \%)$ in $S_{4}$ which was prepared with only vinegar and oil combination. Whereas the lowest moisture content $(63.0 \%)$ was found in $S_{2}$ which was prepared with sugar + oil + vinegar. The second lowest moisture content $(64.0 \%)$ observed in $S_{1}$ which was processed in sugar + oil + vinegar with blenching. The lowest miosture content given by stem amaranth pickle is due to the two-way diffusion of water-sugar-salt and due to frying in oil. which is processed in sugar and oil are probably due to the two-way diffusion of water-sugar, and due to frying in oil.

Hoque (2001) shows that after 120 days at room temperature, the acidity of vegetables pickles ranged from $\mathrm{pH}$ 3.79-4.82 which is similar to that is obtained in this study. It is seen from Table 3 that ash content substantially increased in all the samples.

\section{Microbiological study of stem amaranth pickles}

\section{The total count of bacteria (cfu/g) at different storage periods at room temperature}

The study was performed by standard plate count (SPC) method. The total viable bacterial load was not uniform. The total bacteria were counted as total number of bacteria per gm of sample. The total number of viable bacteria was counted by multiplying the colony forming unit (cfu) with dilution number. The total number of viable bacteria in different samples at different storage period has been shown in Table 4. As shown in Table 4 the total viable bacteria slightly increased with increasing storage period for all products. In Table 4, pickle $S_{1}$ showed minimum count and $S_{5}$ showed maximum count. $S_{1}$ showed minimum count because sugar, vinegar and oil were used in this sample. The total numbers of bacteria are the maximum in the garlic pickle where oil, sugar and preservatives were not used and minimum where oil, sugar and preservatives were used (Aleman, 1998). After bottling of stem amaranth pickles with 2 months storage very little difference was observed in microbiological load compared to 1 month storage for both the cases.

Table 4. The total count of bacteria (cfu/g) at different storage periods at room temperature

\begin{tabular}{|c|c|c|}
\hline Sample No. & Total count (cfu/g) after 1 month & $\begin{array}{c}\text { Total count (cfu/g) after 2 } \\
\text { month }\end{array}$ \\
\hline$S_{1}$ & $30 \times 10^{3}$ & $49 \times 10^{3}$ \\
\hline$S_{2}$ & $30 \times 10^{3}$ & $50 \times 10^{3}$ \\
\hline$S_{3}$ & $56 \times 10^{3}$ & $100 \times 10^{3}$ \\
\hline$S_{4}$ & $40 \times 10^{3}$ & $79 \times 10^{3}$ \\
\hline$S_{5}$ & $66 \times 10^{3}$ & $100 \times 10^{3}$ \\
\hline
\end{tabular}




\section{Visual observation of yeast and mold in developed stem amaranth pickles}

The fungal growth in the developed stem amaranth pickles at different storage periods was examined through visual observation. Up to 2 months of storage no fungal growth was observed. During 4 months of storage the fungal growth was observed in all sample $\left(S_{2}, S_{3}, S_{4}, S_{5}\right)$ except $S_{1}$ because sugar, vinegar and oil were used in this sample (Table 5). Whitish fungal growth was observed at the surface of the pickles. They may come from spices, other ingredients, from the air, or from lid of the jars or closures. At the ends of 6 months of storage all the samples were spoiled except $S_{1}$ and $S_{2}$.

Table 5. Visual observation for fungus growth in developed stem amaranth pickles at different storage periods

\begin{tabular}{|c|c|c|}
\hline Storage period (month) & Sample & Fungal growth \\
\hline \multirow{5}{*}{0} & $\mathrm{~S}_{1}$ & No growth \\
\hline & $\mathrm{S}_{2}$ & No growth \\
\hline & $\mathrm{S}_{3}$ & No growth \\
\hline & $\mathrm{S}_{4}$ & No growth \\
\hline & $\mathrm{S}_{5}$ & No growth \\
\hline \multirow{5}{*}{1} & $\mathrm{~S}_{1}$ & No growth \\
\hline & $\mathrm{S}_{2}$ & No growth \\
\hline & $\mathrm{S}_{3}$ & No growth \\
\hline & $\mathrm{S}_{4}$ & No growth \\
\hline & $\mathrm{S}_{5}$ & No growth \\
\hline \multirow{5}{*}{2} & $\mathrm{~S}_{1}$ & No growth \\
\hline & $\mathrm{S}_{2}$ & No growth \\
\hline & $\mathrm{S}_{3}$ & No growth \\
\hline & $\mathrm{S}_{4}$ & No growth \\
\hline & $\mathrm{S}_{5}$ & No growth \\
\hline \multirow{5}{*}{4} & $\mathrm{~S}_{1}$ & No growth \\
\hline & $\mathrm{S}_{2}$ & Slightly growth \\
\hline & $\mathrm{S}_{3}$ & Slightly growth \\
\hline & $\mathrm{S}_{4}$ & Slightly growth \\
\hline & $\mathrm{S}_{5}$ & Excessive growth \\
\hline \multirow{5}{*}{6} & $\mathrm{~S}_{1}$ & Slightly growth \\
\hline & $\mathrm{S}_{2}$ & Slightly growth \\
\hline & $\mathrm{S}_{3}$ & Excessive growth \\
\hline & $\mathrm{S}_{4}$ & Excessive growth \\
\hline & $\mathrm{S}_{5}$ & Excessive growth \\
\hline
\end{tabular}

\section{Sensory evaluation of stem amaranth pickles}

A taste panel evaluated the consumer's acceptability of developed products. The panelists were requested to assign pickles. The mean score of performence for color, flavor, texture and overall acceptability of stem amaranth pickles are presented in Table 6.

Table 6. Mean score of performence for color, flavor, texture and overall acceptability of various stem amaranth pickles

\begin{tabular}{|c|c|c|c|c|}
\hline \multirow{2}{*}{ Sample code } & \multicolumn{4}{|c|}{ Sensory attributes } \\
\cline { 2 - 5 } & Color & Flavor & Texture & Overall acceptability \\
\hline$S_{1}$ & $8.2^{\mathrm{a}}$ & $8.2^{\mathrm{a}}$ & $7.9^{\mathrm{a}}$ & $8.7^{\mathrm{a}}$ \\
\hline $\mathrm{S}_{2}$ & $8.0^{\mathrm{a}}$ & $8.2^{\mathrm{a}}$ & $7.5^{\mathrm{a}}$ & $7.3^{\mathrm{b}}$ \\
\hline $\mathrm{S}_{3}$ & $7.9^{\mathrm{b}}$ & $6.7^{\mathrm{b}}$ & $6.9^{\mathrm{b}}$ & $6.0^{\mathrm{C}}$ \\
\hline $\mathrm{S}_{4}$ & $7.3^{\mathrm{b}}$ & $6.7^{\mathrm{b}}$ & $6.7^{\mathrm{b}}$ & $5.7^{\mathrm{C}}$ \\
\hline $\mathrm{S}_{5}$ & $7.2^{\mathrm{b}}$ & $6.7^{\mathrm{b}}$ & $6.4^{\mathrm{b}}$ & \\
\hline
\end{tabular}

LSD = 0.6884; $P<0.050$

Sample means having the same letter suffix do not differ at $5 \%(p<0.05)$ level of statistical significance.

A two way analysis of variance was carried out for color preference and result revealed that there was significant $(P>0.05)$ difference in color acceptability among the samples. From Table 6 , it is seen that $S_{1}$ secured the highest score (8.2) for color, 8.2 for flavour, 7.9 for texture, 8.7 for overall acceptability and was ranked as "like very much. It was showed that $S_{5}$ is the lowest value than others. So this indicated that the color of $S_{1}$ is more acceptable than other. 


\section{Storage studies of stem amaranth pickles}

Five different samples of stem amaranth pickle were used for storage studies at room temperature $\left(27^{\circ}\right.$ $33^{\circ} \mathrm{C}$ ) from 0-6 months. The effect of storage time $(0,1,2,4$ and 6 months) on physical properties such as color, flavor and texture of the pickles were studied. The processed stem amaranth pickles were in good condition up to 4 months of storage except those samples which were processed only with oil (without vinegar and sugar) in ambient temperature and at the end of 6 months storage, all the samples were spoiled except $S_{1}$ and $S_{2}$ (Table 7). This may be due to the lack of preservatives because no preservative was used in the stem amaranth pickles. The oil cover, however, influenced the shelf life of the pickles.

Table 7. Storage studies of stem amaranth pickles

\begin{tabular}{|c|c|c|c|c|c|}
\hline $\begin{array}{c}\text { Storage period } \\
\text { (month) }\end{array}$ & Sample & Color & Flavor & Texture & Remarks \\
\hline \multirow{5}{*}{0} & $\mathrm{~S}_{1}$ & No change & No off flavor & Firm & Good \\
\hline & $\mathrm{S}_{2}$ & No change & No off flavor & Firm & Good \\
\hline & $\mathrm{S}_{3}$ & No change & No off flavor & Firm & Good \\
\hline & $\mathrm{S}_{4}$ & No change & No off flavor & Firm & Good \\
\hline & $\mathrm{S}_{5}$ & No change & No off flavor & Firm & Good \\
\hline \multirow{5}{*}{1} & $\mathrm{~S}_{1}$ & No change & No off flavor & Firm & Good \\
\hline & $\mathrm{S}_{2}$ & No change & No off flavor & Firm & Good \\
\hline & $\mathrm{S}_{3}$ & No change & No off flavor & Firm & Good \\
\hline & $\mathrm{S}_{4}$ & No change & No off flavor & Firm & Good \\
\hline & $\mathrm{S}_{5}$ & No change & No off flavor & Firm & Good \\
\hline \multirow{5}{*}{2} & $\mathrm{~S}_{1}$ & No change & No off flavor & Slightly soft & Good \\
\hline & $\mathrm{S}_{2}$ & No change & No off flavor & Slightly soft & Good \\
\hline & $\mathrm{S}_{3}$ & No change & Slightly off flavor & Slightly soft & Good \\
\hline & $\mathrm{S}_{4}$ & No change & No off flavor & Slightly soft & Good \\
\hline & $\mathrm{S}_{5}$ & No change & No off flavor & Soft & Good \\
\hline \multirow{5}{*}{4} & $\mathrm{~S}_{1}$ & No Change & No Off flavor & Slightly soft & Good \\
\hline & $\mathrm{S}_{2}$ & No change & No off flavor & Slightly soft & Good \\
\hline & $\mathrm{S}_{3}$ & Change & No off flavor & Extremely soft & Fair \\
\hline & $\mathrm{S}_{4}$ & No change & Slightly off flavor & Slightly soft & Fair \\
\hline & $\mathrm{S}_{5}$ & Change & Slightly off flavor & soft & Spoiled \\
\hline \multirow{5}{*}{6} & $\mathrm{~S}_{1}$ & No Change & No off flavor & Slightly soft & Good \\
\hline & $\mathrm{S}_{2}$ & Change & No off flavor & soft & Fair \\
\hline & $\mathrm{S}_{3}$ & Change & No off flavor & Extremely soft & Slightly Spoiled \\
\hline & $\mathrm{S}_{4}$ & No Change & Off flavor & Soft & Slightly spoiled \\
\hline & $\mathrm{S}_{5}$ & Change & Off flavor & Extremely soft & Spoiled \\
\hline
\end{tabular}

\section{Conclusion}

The experiment implies the prospect of processing and preservation of stem amaranth pickle as well as investigate the commercial and nutritional aspect of stem amaranth pickle. From the study we found that the microbiological contamination was a great problem for pickle. If we add vinegar and sugar, the microbiological contamination like bacteria, yeast, mold and fungal growth become low. The panelists tasted the products and marked score for color, flavor, texture and overall acceptability. The score of panel test indicated that among five samples, the pickle which was processed in vinegar-sugar-oil mix $\left(S_{1}\right)$ was the most acceptable. Incase of storage, sample $\left(S_{1}\right)$ showed better performance than other samples. It was clear that in all condition sample $\left(S_{1}\right)$ showed better result. As far i know this is the first study about stem amaranth pickle. This study indicates a good prospect of processing of stem amaranth by pickling. Thus a large number of skilled and semiskilled, even unskilled person would be employed in the relevant industries which will help to remove unemployment problem in any country.

\section{Reference}

Aleman, K. 1998. Heat sensitization of Bacillus subtillis spores by selected spices. Journal of Food Safety. 9(2): 83-96

AOAC, 2004. Association of Analytical Chemist, Nutritional Analysis Laboratory, Wilson, NC

APHA, 2004. American Public Health Association, Standard Methods for Examination of Water and Wastewater. $19^{\text {th }}$ edition, Washington, DC.

BBS, 2010. Monthly statistical Bulletin, Bangladesh Bureau of Statistics, Statistics division, Ministry of planning, Govt. of the Peoples Republic of Bangladesh, Dhaka. P. 155.

Hoque, F. 2001. Processing of pickles from mango, tomato and green chillies. MS Thesis. Department of Food Technology and Rural Industries. Bangladesh Agricultural University, Mymensingh. P. 66.

Ranni, U.M. 1992. Studies on quality standards of India commercial pickle. Indian Food Packer, India. 40(6): P. 27-33.

Srivastava, R. P. and Kumar, S. 2003. Fruit and vegetable preservation. Indian Food Packer,Lucknow. P. 382 